\title{
DEVELOPMENT OF CIRCULAR ECONOMY CONCEPT: HISTORICAL BACKGROUND
}

\author{
YULIIA MAKSYMIV, VALENTYNA YAKUBIV, IRYNA HRYHORUK, VIKTORIIA KRAVTSIV
}

\begin{abstract}
Nowadays, sharp economic growth has increasingly depended on utilizing different resources causing environmental issues and hindering sustainable development. Consequently, governments of developed countries, the public sector, representatives of business structures, and scientists look at the circular economy as a way to support achieving sustainable development goals. The article aims at researching the historical background of the development of circular economy, analyzing the basic approaches and their possible usage for spreading this concept in developing countries, such as Ukraine. It is mentioned that the concept of circular economy cannot be traced back to a single author or date when it appeared. The concept of circular economy was inspired by several schools of thought with overlapping approaches, which demonstrates the relevance of distinguishing evolutionary phases and framings of a concept. The article presents a historical overview of the development of the concept of circular economy since the 1960s. The stages of adoption of regulations in the EU in the field of promoting the transition to a circular economy are highlighted, key milestones and key actions that actively began in 2015 and continue to this day, are described. This positive experience should be taken as a basis in developing countries, where the circular economy is in its infancy. The article also analyzes the highly cited scientific papers in the Scopus Scientometric Database and the basic definitions of the concept of "circular economy". Our findings indicate that the circular economy necessitates a systemic shift in the state policy of Ukraine, as well as economic science, and it should be aimed at developing a clear strategy and improving basic regulations in this area to increase the social responsibility of both businesses and local communities. The growth of a circular economy will benefit everyone within the limits of this planet. Keywords: circular economy, history of development of circular economy, diagrams of circular economy, waste.

JEL Classification: Q53, Q56, P41.
\end{abstract}




\section{INTRODUCTION}

In the last decade, there is a growing interest in the circular economy in international politics, academia, and among conscious citizens and business structures. It is "a field which is possibly the most vibrant field right now in the realms of sustainability research" [1]. This is due to the awareness of the need to find ways to put into practice the idea of sustainable development, which has become quite ephemeral in achieving its goals. There is even an opinion that the concept of sustainable development has been called too vague to be complementary and has thus started to lose momentum [2;3, p.2 ff.]. The abstractness of the concept of sustainable development is partially eliminated with the adoption of the Global Framework for Indicators for Sustainable Development Goals. Having received the target in the form of 17 SDGs, it became clear that the traditional linear economic system needs to be changed to a circular model of its development [4, p. 1-2], the main ideas of which originated in the middle of the 20th century and are gaining new significance nowadays. The interest in the circular economy is also growing because it is viewed as an operationalization for businesses to implement the much-discussed concept of sustainable development $[5 ; 6]$.

According to the Scopus Scientometric Database, over the past 10 years, scientists from Italy, Great Britain, China, Spain, Germany, the United States, the Netherlands, Sweden, etc. have shown the greatest interest in studying the concept of a circular economy. Unfortunately, in Ukraine, as in many other developing countries, very little scientific work is devoted to the problem of circular economy development, but there are some developments related to waste management $[7 ; 8]$ as an important part of the circular economy. Given the many unresolved issues at the level of theoretical rethinking, regulation, and practical implementation of the principles of the circular economy, this is a potentially important area of research in Ukraine and other developing countries.

\section{Literature ReVieW, Generalization OF MAin Statements}

Historically, we have seen a sharp revival of scientific interest in the circular economy since 2016, as evidenced by the sharp increase in the number of peer-reviewed publications published in journals included in the Scopus Database (keyword search of "circular economy"). In 2015, 78 articles were published, in 2016 - 207; in 2017 - 471; 2018 - 800; 2019 - 1243 articles; in 2020 - 1934 (fig. 1) [9]. Looking at the current trend, in 2021 the interest rate in the circular economy is likely to increase. A certain limitation of these data is that there is still some inconsistency in the use of the established phrase for the characteristics of the circular economy, as they also use terms such as "closed-loop economy", "looped economy", etc. Also "cradle-to-cradle", laws of ecology, performance economy, regenerative design, industrial ecology, biomimicry, blue economy, waste management, etc. have a theoretical impact on the circular economy.

Circular economy (CE) dates back much longer than the current use of the notion. In many parts of the globe, most notably in Europe, circularity has a long history [10, p. 248]. Despite the revival of interest in the study of the possibility of transition from a linear economic model to a circular one, the historical aspects of the development of the concept of a circular economy are revealed only in some works. In particular, D. Reike, W. Vermeulen, S. Witjes [10], who described the Circular Economy "as an Evolution in Three Phases"; the research objectives of K. Winans, A. Kendall, H. Deng was a review of the history of the CE concept to provide a context for a critical examination of how it is applied currently [11]; Ellen MacArthur [12, p. 26-27] notes that "the circular economy concept has deep-rooted origins and cannot be traced back to one single date or author" and he considers the historical development of the circular economy through the allocation of schools of thought: regenerative design, performance economy, cradle to cradle, industrial ecology, biomimicry. 


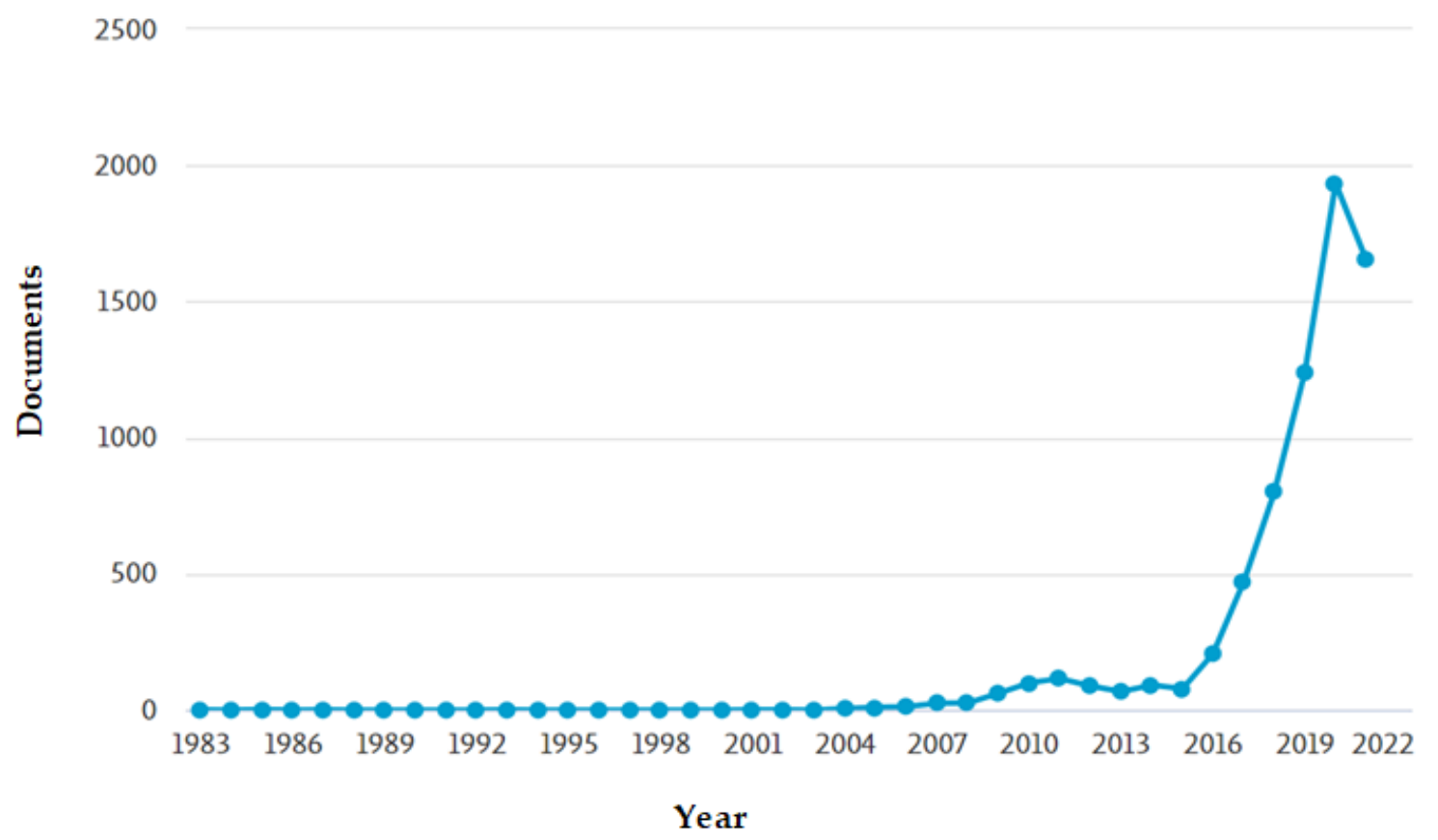

Fig. 1. Number of scientific publications per year on the keyword "circular economy" in the Scopus Database.

* Source: https://www.scopus.com/ (data as of July 2021)

P. Ekins [13, p. 4-17] in a review of the historical background of the circular economy, writes about the origins of this concept, the main idea of which is from two directions: 1) relating to the flow of materials through an economy; 2) considering the economic conditions as factors for causing such a flow. The first direction is related to the terms "industrial symbiosis" and "industrial ecology", which were used in geography as a science of economic activity to describe the determinants of the location of industries in order to use resources efficiently and avoid waste in the 1940s.

Thus, P. Ekins [13] points out that the main economic research in this area is the work of Boulding in 1966, which provides both philosophical and practical basis for modern literature on the circular economy. P. Ekins writes "It is truly astonishing how this single brief paper (with just five references) set out most of the insights on which current circular economy thinking is now based, and little less astonishing how long these insights took to become more firmly entrenched in thinking about the environment, resources and the economy". Boulding describes the Earth as a closed circular system with limited ability to assimilate, and from this it is concluded that the economy and the environment must coexist in equilibrium. In fact, the basics of circular economics in philosophical, ethical and economic dimensions are described, but without mentioning the term itself.

In one of his speeches, dated 1970, the President of the American Association for the Advancement of Science presented ideas connected with the circular economy, and this prompted reflection on the subject: "The object of the next industrial revolution is to ensure that there will be no such thing as waste, on the basis that waste is simply some substance that we do not yet have the wit to use ... In the next industrial revolution there must be a loop back from the user to the factory, which the industry must close. If the industry should take upon itself the task of closing this loop, then its original design of the article would include features facilitating their return and remaking" [14].

In scientific sources [13] there is an opinion that this (Fig. 2) is the first schematic description of the circular economy (W. Stahel calls it "self-replenishing economy"). This is prompted by the content of the figure, as well as the fact that for comparison the author gives a schematic representation of the linear economy Fig. 3, noting: "Today, industrial activity involves a linear production-consumption system with inbuilt environmental deterioration at both ends" [15]. This is a quote from 1982, which is still relevant for most industries today, despite the evolutionary development of the concept of a circular economy. 


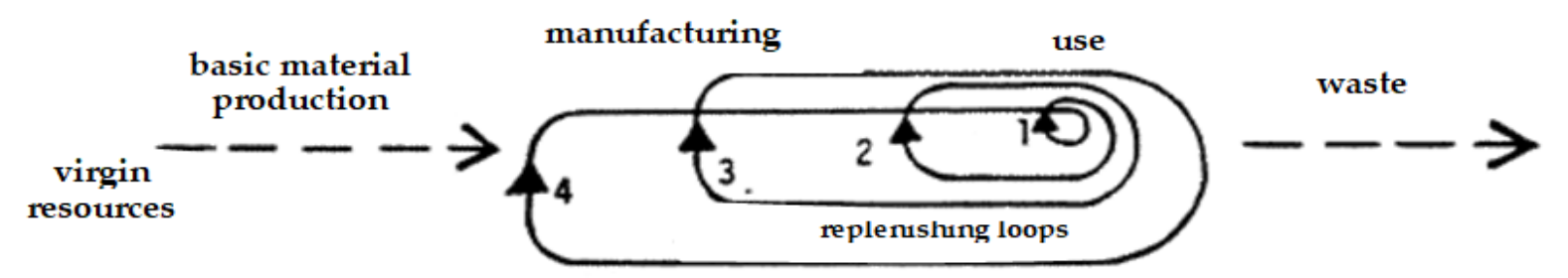

independence of the life-times of inter-compatible systems, products and components

\section{Loop 1:REUSE Loop 2:REPAIR Loop 3:RECONDITIONING Loop 4: RECYCLING}

Fig. 2. An early depiction of a circular economy (the self-replenishing system).

* Source: reproduced based on [15]

Describing fig. $1 \mathrm{~W}$. Stahel writes: "A society relying on this self-replenishing economy is building on existing wealth and applying economics to optimize the total life-span of goods and products. Financial and resource management is now aimed at reducing total long-term utilization costs). The effectiveness of this spiral-loop system is greatly enhanced by a built-in inertia which keeps the loops as small as possible: do not recondition something that can be repaired, do not recycle a product that can be reconditioned economically".

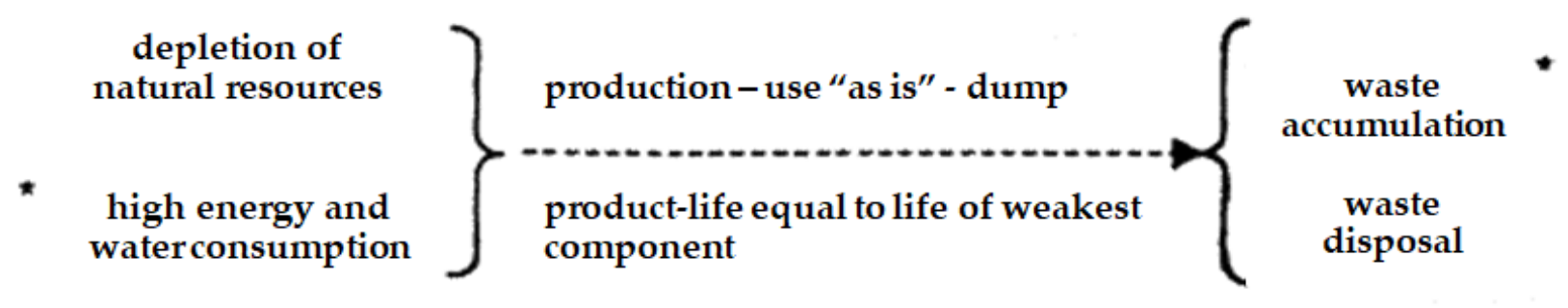

Fig. 3. A linear production-consumption system with inbuilt environmental deterioration at both ends * Source: reproduced based on [15]

The researchers M. Andersen [16], P. Ghisellini et al. [5] and B. Su et al. [17] report that the concept of circular economy was introduced in 1989 by D. Pearce and R. Turner [18], inspired by the work of Boulding. The authors described "how natural resources influence the economy by providing inputs for production and consumption as well as serving as a sink for outputs in the form of waste, they investigate the linear and open-ended characteristics of contemporary economic systems". However, it was not until 1990 that the circular economy was fully defined and described as such in economic terms. D. Pearce and R. Turner [19] contrast (circular) natural systems with (linear) economic systems, distinguish between capital stocks and the flows from them and go back to Boulding's paper to emphasize the importance of the laws of thermodynamics.

Fig. 4 shows a simple circular economy diagram, where "recycling" D. Pearce and R. Turner [19] is considered as the main process underlying the circularity, and in fig. 5 "complete picture" of a circular economy by Pearce and Turner. Since then, the understanding of the processes underlying the circular economy has expanded significantly: "recovery", "repurpose", "remanufacture", "refurbish", "repair", "reuse", "reduce", "rethink", "refuse", which will be described in detail in future studies. 


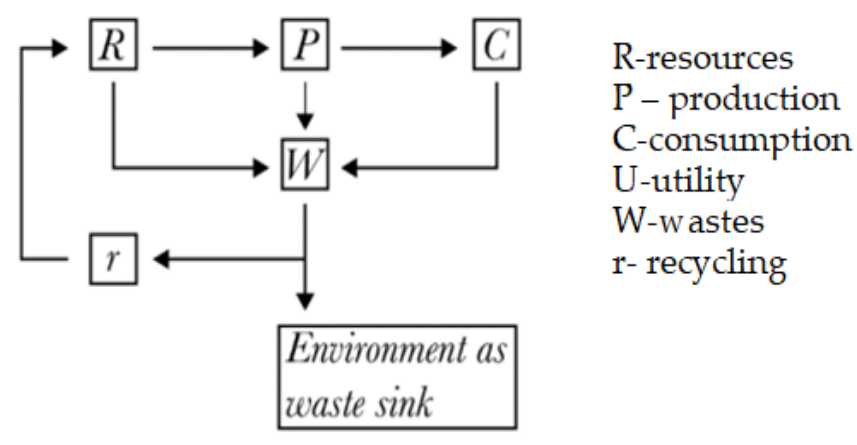

* Source: [19]

Fig. 4. Simple circular economy diagram.
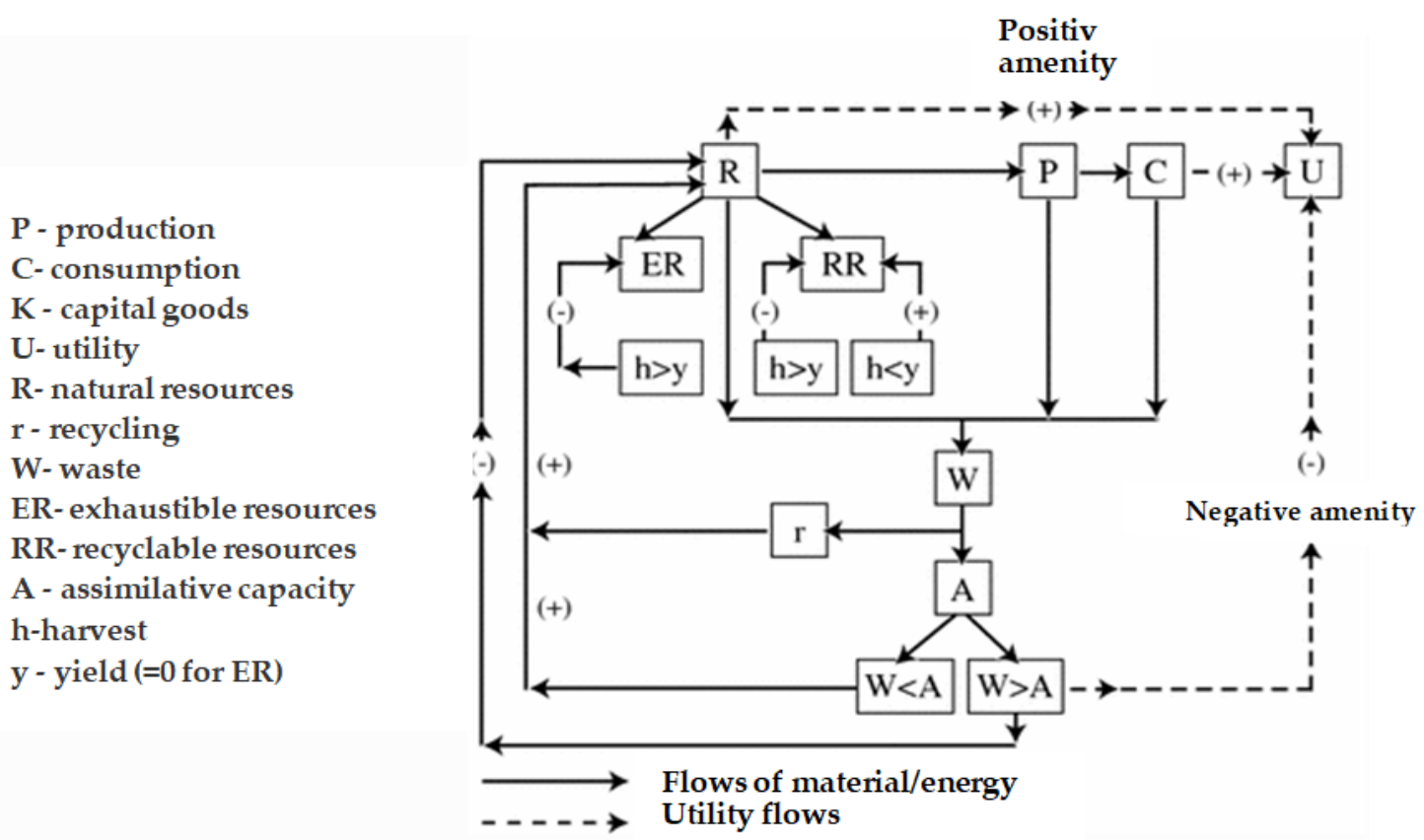

* Source: [19]

Fig. 5. "Complete picture" of a circular economy by D. Pearce and R. Turner.

The next decade was marked by relatively little progress in the development of circular economy ideas, and only in 2013 The Ellen MacArthur Foundation in partnership with consulting firm McKinsey \& Company and representatives of big business (Caterpillar, Cyberpac, Desso, EPEA, Foresight Group, ISE, Marks \& Spencer and others) published research in which, in addition to the general aspects of the circular economy, the possibilities of the practical application of the ideas of the concept are described. The first publication of the Ellen MacArthur Foundation [12, p.24] presents a circular economy in the form of a system diagram - "butterfly" - which illustrates the continuous flow of technical and biological materials through the "value circle". Since then, this diagram is most often used as a basis for describing the circular economy.

As we can see from the historical point of view, the concept of circular economy dates back to the 1970s, but in terms of active implementation, "CE implementation worldwide is still in its early stages, and mainly focuses on recycling rather than reuse" [20, p.11]. This is stated in one of the most cited articles in the Scopus Scientometric Database [20, p.11], it should also be borne in mind that thus far, $95 \%$ of scholarly works on CE have focused on developed economies [21]. 


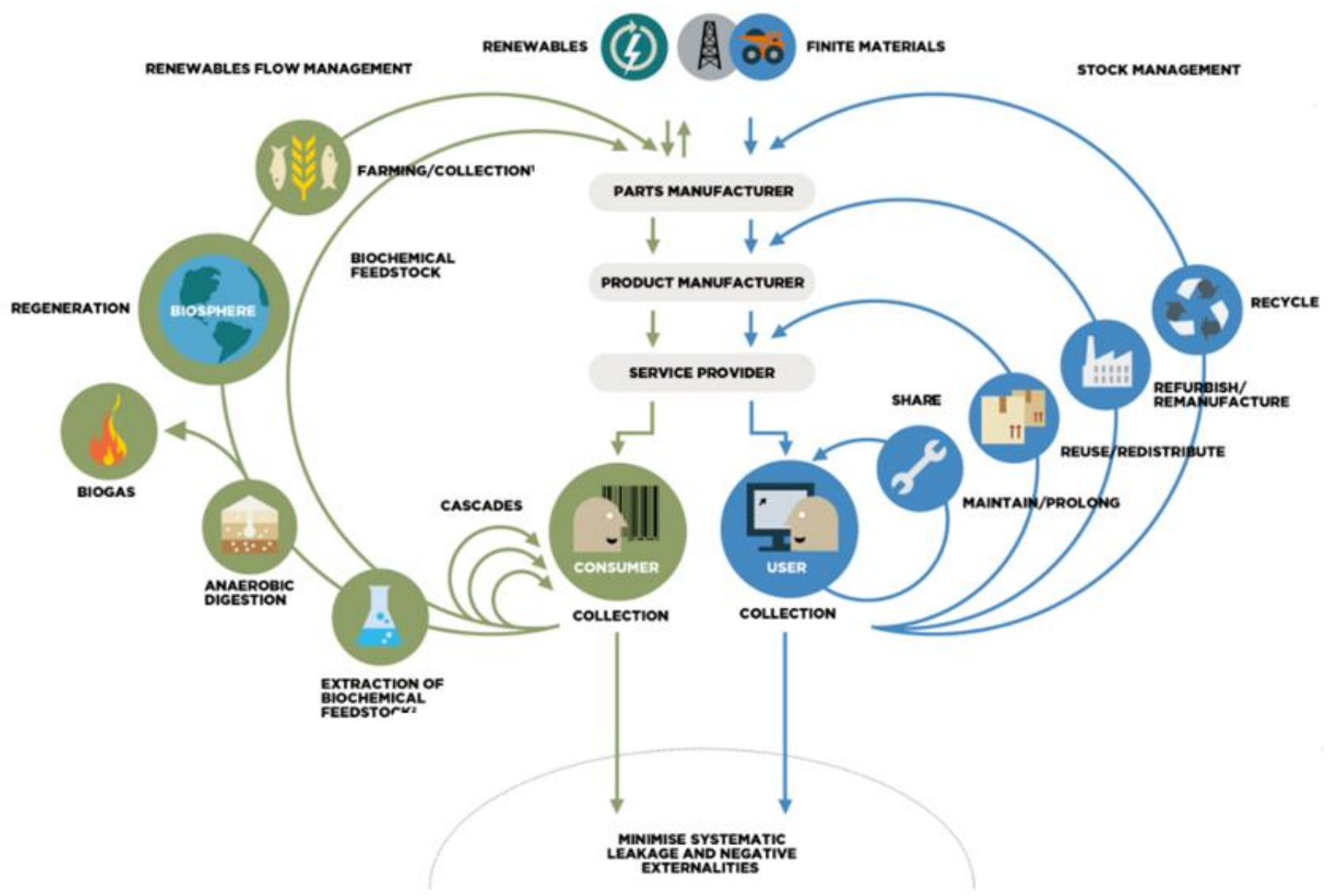

Fig. 6. The circular economy - an industrial system that is restorative by design.

* Source: $[12$, p. 24]

However, in developing countries, including Ukraine, the problem of inefficient waste management as an important priority of the circular economy remains national. L. Diaz [22, p.1], in this context, indicates that the reason for this is the lack of political will to solve the problem, lack of national policy on solid waste management, absence of rules and regulations, insufficient funds allocated to solve the problem, a severe absence of educational programs at all levels, and last but not least, no policies related to preserving or creating a "circular economy". Search for ways to solve such problems, which are typical for Ukraine, are prospects for further research in this direction.

Regardless of whether the country's economy is at the stage of implementing a circular economy or at the stage of expanding its scale, an important basis for these processes should be legal regulation. Therefore, the next important stage in the development of the circular economy is the period when at the legislative level systematically adopted regulations aimed at stimulating the transition of Europe to a circular economy. Key stages of regulations in the EU in terms of years are given in table 1. Active steps in this direction began in 2015 and continue to this day.

It should be noted that such an important process of circular economy as waste recycling is regulated by law much faster in developed countries and they have already achieved significant success. For example, in Germany the Circular Economy is integrated into national laws, as early as 1996; in Japan in 2002; in China in 2009.

Over the years of development of the concept of circular economy, a number of definitions of this concept have been formed, without dwelling in this article on their detailed analysis, note that J. Kirchherr et al [23, p. 226), M. Geissdoerfer et al. [1, p. 759] and E. Schut et al. [24, p. 15] indicate that the most famous definition of a circular economy is the interpretation given by the Ellen MacArthur Foundation [12, p.7] which reads:

" $[\mathrm{CE}]$ an industrial system that is restorative or regenerative by intention and design. It replaces the 'end-of-life' concept with restoration, shifts towards the use of renewable energy, eliminates the use of 
toxic chemicals, which impair reuse, and aims for the elimination of waste through the superior design of materials, products, systems, and, within this, business models".

\begin{tabular}{|c|c|c|}
\hline Year & Name of action & Key objectives \\
\hline 2015 & $\begin{array}{l}\text { Adoption of the first circular } \\
\text { economy action plan for the } \\
\text { European Union }\end{array}$ & $\begin{array}{l}\text { Actions for stimulating Europe's transition towards a } \\
\text { circular economy, boosting global competitiveness, and } \\
\text { fostering sustainable economic growth. }\end{array}$ \\
\hline 2016 & $\begin{array}{l}\text { Adoption of Ecodesign Working } \\
\text { Plan } 2016 \text { - } 2019\end{array}$ & $\begin{array}{l}\text { Actions for promoting a transition towards a more circular } \\
\text { economy in the EU through a number of measures } \\
\text { covering the whole life-cycle of products and materials } \\
\text { with the focus on energy efficiency improvements. }\end{array}$ \\
\hline 2018 & $\begin{array}{l}\text { Adoption of a circular economy } \\
\text { package for the European Union }\end{array}$ & $\begin{array}{l}\text { A series of regulations to help businesses and consumers in } \\
\text { the EU to make the transition to a stronger and more } \\
\text { circular economy with more sustainable use of resources. }\end{array}$ \\
\hline 2019 & $\begin{array}{l}\text { Adoption of the final circular } \\
\text { economy action package }\end{array}$ & $\begin{array}{l}\text { Initiatives to boost circular economic approaches during } \\
\text { the entire life cycle of products, including sustainable } \\
\text { consumption and responsible waste management in the } \\
\text { EU. }\end{array}$ \\
\hline 2019 & Adoption of fertilizers regulation & $\begin{array}{l}\text { Rules on the making available fertilizers produced from } \\
\text { phosphate minerals and organic or secondary raw } \\
\text { materials on the market of the EU. It enhanced their } \\
\text { production and marketing on a large scale. }\end{array}$ \\
\hline 2019 & Directive on single-use plastics & $\begin{array}{l}\text { Regulations for reducing the volume and impact of ten } \\
\text { plastic products on the environment, in particular the } \\
\text { marine environment. }\end{array}$ \\
\hline 2019 & $\begin{array}{l}\text { Eco-design requirements for external } \\
\text { power supplies }\end{array}$ & $\begin{array}{l}\text { Regulations for the use of energy-related products to make } \\
\text { lower resource consumption and reach less environmental } \\
\text { impact as a result (for instance, the restriction on the use } \\
\text { of halogenated flame retardant (in televisions, computer } \\
\text { monitors, signage display)). }\end{array}$ \\
\hline 2019 & Adoption of European Green Deal & $\begin{array}{l}\text { Actions for boosting the efficient use of resources by } \\
\text { moving to a clean, circular economy and stopping climate } \\
\text { change, to make Europe climate neutral in } 2050 \text {. }\end{array}$ \\
\hline 2020 & $\begin{array}{l}\text { Adoption of a new circular economy } \\
\text { action plan }\end{array}$ & $\begin{array}{l}\text { Actions to reduce pressure on natural resources and create } \\
\text { sustainable growth and jobs. Regulations are focused on } \\
\text { how to prevent waste and to keep the resources in the EU } \\
\text { economy for as long as possible. }\end{array}$ \\
\hline
\end{tabular}

Tab. 1. Advancing to a circular economy: key stages of regulations in the EU.

* Source: adapted by the authors based on [25]

For a fuller modern understanding of the concept of circular economy, it is also worth giving the definition proposed by the authors of the highly cited article (more than 1000 references in Scopus) which comprehensively and systematically analyzes 114 definitions of a circular economy. Yes, J. Kirchherr et al [23, p. 224-225] offers the following definition: "A circular economy describes an economic system that is based on business models which replace the 'end-of-life' concept with reducing, alternatively reusing, recycling and recovering materials in production/distribution and consumption processes, thus operating at the micro level (products, companies, consumers), meso level (eco-industrial parks) and macro level (city, region, nation and beyond), with the aim to accomplish sustainable development, which implies creating environmental quality, economic prosperity and social equity, to the benefit of current and future generations". 


\section{CONCLUSIONS}

A historical review of the development of the circular economy shows that despite the long-standing emergence of its main ideas, in international politics, academia, and among conscious citizens and businesses the interest in the circular economy is growing during the last decade. This is due to the growing understanding of various stakeholder groups in the practical possibilities of the circular economy's contribution to sustainable development, as the European Union, China, and other countries have a positive experience in the implementation of projects in terms of the use of waste as secondary raw material and the creation of products with a long-life cycle, the creation of generally circular business processes. The introduction of a circular economy instead of a linear economic model requires the improvement of the regulatory framework, and in the last decade the European Union has been carrying out systematic work in this direction. However, there are many unresolved issues in developing countries, where the level of development of the circular economy requires important steps: from developing a clear strategy and improving basic regulations in this area to increasing the social responsibility of both businesses and local communities.

\section{REFERENCES}

[1] Geissdoerfer M., Savaget P., Bocken N., Hultink E. The circular economy - A new sustainability paradigm? Journal of Cleaner Production, 143 (2017), 757-768. doi:10.1016/j. jclepro.2016.12.048

[2] Van den Brande K., Happaerts S., Bouteligier S. Keeping the sustainable development flame alive. Broker 2011.

[3] Peltonen L. Notes on Multilevel Governance and Climate Change. 2017. Available at: http://cor.europa.eu/en/activities/governance/documents/1a0bb3a3-0768-4c90-a732-3074c47f7b7c.pdf.

[4] Maksymiv Y., Yakubiv V., Pylypiv N., Hryhoruk I., Piatnychuk I., Popadynets N. Strategic challenges for sustainable governance of the bioeconomy: preventing conflict between SDGs. Sustainability, 13 (15:8308) (2021). doi: 10.3390/su13158308

[5] Ghisellini P., Cialani C., Ulgiati S. A review on circular economy: the expected transition to a balanced interplay of environmental and economic systems. Journal of Cleaner Production, 114 (2016), 11-32. doi: 10.1016/j.jclepro.2015.09.007

[6] Murray A., Skene K., Haynes K. The circular economy: an interdisciplinary exploration of the concept and application in a global context. Journal of Business Ethics, 140 (3) (2017), 369-380. doi: 10.1007/s10551015-2693-2

[7] Kolodiychuk I.A. Formation of territorially balanced waste management systems: regional dimension: monograph, Lviv: SI Dolishny Institute for Regional Studies of the National Academy of Sciences of Ukraine, 2020. (in Ukrainian)

[8] Maksymiv Yu. V. Complex Use of Raw Materials in Production of Solid Biofuel by Woodworking Enterprises: Accounting and Analytical Aspect. Ivano-Frankivsk: Printing Folio, 2015. (in Ukrainian)

[9] Scopus Preview. Available at: https://www.scopus.com/ (data as of July 2021)

[10] Reike D., Vermeulen W. J.V., Witjes S. The circular economy: New or Refurbished as CE 3.0? - Exploring Controversies in the Conceptualization of the Circular Economy through a Focus on History and Resource Value Retention Options. Resources, Conservation and Recycling. 135 (2018), 246-264. doi: 10.1016/j.resconrec.2017.08.027

[11] Winans K., Kendall A., Deng H. The history and current applications of the circular economy concept. Renewable and Sustainable Energy Reviews. 68 (1) (2017), 825-833. doi:10.1016/j.rser.2016.09.123

[12] Ekins P., Domenech T., Drummond P., Bleischwitz R., Hughes N., Lotti L. “The Circular Economy: What, Why, How and Where", Background paper for an OECD/EC Workshop on 5 July 2019 within the workshop series "Managing environmental and energy transitions for regions and cities", Paris. 
[13] Spilhaus A. Resourceful Waste Management. Science News, 89 (25) (1966), 486-488; 498. Available at: https://www.jstor.org/stable/pdf/3950241.pdf?refreqid=excelsior\%3Ae34f7b126ddfbaa3a2243d304e104c 50.

[14] Stahel W. 'Product-Life Factor', Mitchell Prize Winning Paper, Product-Life Institute, 1982. Available at: http://www.product-life.org/en/major-publications/the-product-life-factor.

[15] Andersen M.S. An introductory note on the environmental economics of the circular economy. Sustain. Sci, 2 (2007), 133-140.

[16] Su B., Heshmati A., Geng Y., Yu X. A review of the circular economy in China: moving from rhetoric to implementation. Journal of Cleaner Production, 42 (2013), 215-227.

[17] Pearce D., Turner R. Economics of Natural Resources and the Environment. Johns Hopkins University Press, Baltimore, 1989.

[18] Pearce D., Turner R. Economics of Natural Resources and the Environment.Harvester Wheatsheaf, Hemel Hempstead, Herts., UK, 1990.

[19] Ghisellini P., Cialani C., Ulgiati S. A review on circular economy: the expected transition to a balanced interplay of environmental and economic systems. Journal of Cleaner Production, 114 (2016), 11-32. doi:10.1016/j.jclepro.2015.09.007

[20] Friant M., Vermeulen W., Salomone R. A typology of circular economy discourses: navigating the diverse visions of a contested paradigm. Resour, Conversation Recycnling, 161 (2020). doi: 10.1016/j.resconrec.2020.104917

[21] Luis F Diaz. Waste management in developing countries and the circular economy. Waste Management $\mathcal{E}$ Research, 35 (1) (2017), 1-2. doi:10.1177/0734242X16681406

[22] Kirchherr J., Reike D., Hekkert M. Conceptualizing the circular economy: An analysis of 114 definitions. Resources, Conservation \& Recycling, 127 (2017), 221-232. doi:10.1016/j.resconrec.2017.09.005

[23] Schut E., Crielaard M., Mesman M. Circular Economy in the Dutch Construction Sector: A Perspective for the Market and Government. 2015. Available at. http://www. rivm.nl/dsresource?objectid=806b288e3ae9-47f1-a28f-7c208f884b36\&type $=$ org\& disposition=inline.

[24] European Commission. First circular economy action plan. Available at: https://ec.europa.eu/environment/topics/circular-economy/first-circular-economy-action-plan_en

Address: Yuliia Maksymiv, Valentyna Yakubiv, Iryna Hryhoruk, Viktoriia Kravtsiv. Vasyl Stefanyk Precarpathian National University, 57, Shevchenko Str., Ivano-Frankivsk, 76018, Ukraine.

E-mail: yuliia.maksymiv@pnu.edu.ua, valentyna.yakubiv@pnu.edu.ua, iryna.hryhoryk@pnu.edu.ua, viktoriia.kravtsiv@pnu.edu.ua.

Received: August 28, 2021; revised: October 23, 2021.

Максимів Юлія, Якубів Валентина, Григорук Ірина, Кравців Вікторія. Розвиток концепції циркулярної економіки: історичний огдяд. Журнал Прикарпатського університету імені Василя Стефаника, 8 (3) (2021), $120-129$.

У наш час стрімке економічне зростання все більше залежить від використання різних ресурсів, що спричиняе екологічні проблеми та заважає сталому розвитку. Отже, уряди розвинених країн, державний сектор, представники бізнес-структур, науковці розгдядають кругову економіку як спосіб підтримки досягнення цілей сталого розвитку. Метою статті є дослідження історичних передумов розвитку циркулярної економіки, аналіз основних підходів та їх можливого використання для поширення цієї концепції в країнах, що розвиваються, наприклад в Україні. Зазначається, що виникнення поняття циркулярної економіки не можна простежити за одним автором або датою його появи. Концепція циркулярної економіки була натхненна декількома науковими школами 3 
підходами, що перетинаються, що демонструє актуальність розрізнення еволюційних фаз і структур концепції. У статті подано історичний огляд розвитку концепції циркулярної економіки починаючи 3 1960 років. Наведено етапність прийняття нормативно-правових актів в ЄС в сфері сприяння переходу до циркулярної економіки, ключові віхи та основні дії, які активно розпочалися у 2015 році і тривають до сьогодні. Цей позитивний досвід має бути прийнятий за основу і в країнах що розвиваються, де циркулярна економіка є на початковому етапі свого розвитку. Також у статті проаналізовано високо цитовані в наукометричній базі Scopus наукові праці й основні визначення поняття "циркулярної економіки”. Наші висновки свідчать про те, що циркулярна економіка потребує системної роботи як у державній політиці України, так і в економічній науці, і вона має бути спрямована на вироблення чіткої стратегії та вдосконалення базових нормативних актів у цій сфері для підвищення соціальної відповідальності як бізнесу, так і територіальних громад. Зростання циркулярної економіки принесе користь кожному в межах цієї планети.

Кдючові слова: циркулярна (кругова) економіка, історія розвитку циркулярної економіки, діаграми циркулярної економіки, відходи. 